\title{
Enzyme-assisted extraction of polyphenols from green yerba mate
}

\author{
Extração de polifenóis de erva-mate verde assistida por \\ enzimas
}

\author{
Ana Carolina Winkler Heemann ${ }^{1 *}$ (D), Rodrigo Heemann², Paloma Kalegari", \\ Michele Rigon Spier ${ }^{4}$, Elizabeth Santin ${ }^{1}$ \\ ${ }^{1}$ Universidade Federal do Paraná (UFPR), Departamento de Medicina Veterinária, Curitiba/PR - Brasil \\ ${ }^{2}$ Heide Extratos Vegetais, Pinhais/PR - Brasil \\ ${ }^{3}$ Universidade Federal do Paraná (UFPR), Departamento de Bioquímica, Curitiba/PR - Brasil \\ ${ }^{4}$ Universidade Federal do Paraná (UFPR), Departamento de Engenharia Química, Curitiba/PR - Brasil
}

*Corresponding Author: Ana Carolina Winkler Heemann, Universidade Federal do Paraná (UFPR), Departamento de Medicina Veterinária, Rua dos Funcionários, 1540, Juvevê, CEP: 80035-050, Curitiba/PR - Brasil, e-mail: anaheemann@ufpr.br

Cite as: Heemann, A. C. W., Heemann, R., Kalegari, P., Spier, M. R., \& Santin, E. (2019). Enzyme-assisted extraction of polyphenols from green yerba mate. Brazilian Journal of Food Technology, 22, e2017222. https://doi.org/10.1590/1981-6723.22217

\begin{abstract}
The enzyme-assisted extraction of bioactive compounds from plants has been studied as an alternative green technology and the carbohydrases have been candidates to improve the extraction process of numerous such compounds from plants. Polyphenols are secondary plant metabolites, generally involved in the defense against different types of stress and yerba mate (Ilex paraguariensis A. St.-Hil., Aquifoliaceae) is a natural source of these antioxidant compounds. The aim of this work was to evaluate the enzyme-assisted extraction of polyphenols from green yerba mate employing response surface methodology (RSM), in order to determine the best extraction conditions. The independent variables were temperature $\left(33.2\right.$ to $\left.66.8^{\circ} \mathrm{C}\right)$, enzyme concentration (0 to $336 \mathrm{FGBU} / 100 \mathrm{~g}$ ), reaction time (19 to 221 minutes) and $\mathrm{pH}$ (2.82 to 6.18). The use of carbohydrases increased the extraction of polyphenols from about $38.67 \%$ to $52.08 \%$. The present results showed that all the independent variables were significant at the linear level and that temperature and $\mathrm{pH}$ were not significant at the quadratic level. The interactions of temperature and $\mathrm{pH}$; enzyme and reaction time; and enzyme and $\mathrm{pH}$ were significant. The regression model presented a determination coefficient $\left(R^{2}\right)$ close to 0.85 and a fitted value close to 0.45 . Considering the results of this study and their industrial viability, the best conditions for the extraction of polyphenols from green yerba mate are a temperature of $50.0^{\circ} \mathrm{C}$, enzyme concentration of $168 \mathrm{FGB} / 100 \mathrm{~g}$, reaction time of 120 minutes and $\mathrm{pH}$ value of 4.50. This study was the first RSM-based report of the optimization of the enzyme-assisted extraction of total phenolic compounds from green yerba mate.
\end{abstract}

Keywords: Carbohydrases; Beta-glucanase; Polyphenols; Bioactive compounds; llex paraguariensis; Response surface methodology. 


\section{Resumo}

A extração de bioativos de plantas assistida por enzimas tem sido estudada como uma tecnologia verde alternativa. As carboidrases foram candidatas para melhorar o processo de extração de numerosos compostos bioativos de plantas. Os polifenóis são metabólitos secundários de plantas geralmente envolvidos em defesa contra diferentes tipos de estresse. A erva-mate (Ilex paraguariensis A. St.-Hil., Aquifoliaceae) é uma fonte natural desses compostos antioxidantes. O objetivo deste trabalho foi avaliar a extração de polifenóis auxiliada por enzimas para determinar as melhores condições para o uso, empregando metodologia de superfície de resposta (RSM). As variáveis independentes foram: temperatura $\left(33,2\right.$ to $66,8^{\circ} \mathrm{C}$ ), concentração enzimática (0 to $336 \mathrm{FGB} / 100 \mathrm{~g}$ ), tempo de reação (19 to 221 minutos) e pH $(2,82$ to 6,18$)$. O uso de carboidrase aumentou a extração de polifenóis de $38,67 \%$ para $52,08 \%$. Os resultados mostraram que todas as variáveis independentes foram significativas a nível linear e a temperatura e o $\mathrm{pH}$ não se mostraram significativos nos níveis quadráticos. As interações de temperatura e $\mathrm{pH}$, tempo de reação e concentração da enzima e pH e concentração da enzima foram significativas. O modelo de regressão apresentou coeficiente de determinação $\left(R^{2}\right)$ próximo de 0,85 e ajustado perto de 0,45 . Considerando-se os resultados deste estudo e a viabilidade industrial, as melhores condições para a obtenção de polifenóis de erva-mate são temperatura de $50,0^{\circ} \mathrm{C}$, concentração de enzima $168 \mathrm{FGBU} / \mathrm{g}$ de folhas secas, 120 minutos de tempo de reação e pH 4,5. Este estudo é o primeiro relato de otimização da extração de polifenóis de erva-mate verde assistida por enzimas baseada em RSM.

Palavras-chave: Carboidrases; Beta-glucanase; Polifenóis; Compostos bioativos; llex paraguariensis; Metodologia de superfície de resposta.

\section{Introduction}

Ilex paraguariensis A. St.-Hil. is a plant that belongs to the family Aquifoliaceae and is widely distributed in Latin American countries such as Brazil, Argentina, Paraguay and Uruguay (Anesini et al., 2012). In these countries, "mate" is a tea made from the infusion of the dry leaves of this plant and is one of the most consumed non-alcoholic beverages. The discovery of various substances with important biological activities in mate has also increased its consumption in other countries (Mejia et al., 2010), and due to this interest, there has been an increase in research related to the properties of yerba mate in the last 20 years (Bracesco et al., 2011). In these studies it was shown that mate had antioxidant, antibacterial, antiviral, antitumor and antimutagenic properties (Bastos et al., 2007; Geetha et al., 2004; Heck et al., 2008). Regarding its composition, the yerba mate extract presents flavonoids and vitamins such as vitamins $\mathrm{A}, \mathrm{B}, \mathrm{C}$ and $\mathrm{E}$, amongst other substances (Menini et al., 2007). Furthermore, the yerba mate extract is very rich in polyphenols, with levels even higher than those in green tea and wines (Gugliucci et al., 2009).

The extraction efficiency of polyphenols from yerba mate is influenced by herb particle size, solvents, $\mathrm{pH}$, time, temperature and agitation (Craft et al., 2012). The conventional extraction of polyphenols uses solvents such as ethyl alcohol or derived aqueous mixtures and has been used by many researchers (Bae et al., 2015). However, another method using enzymes has been developed and used to obtain plant-derived polyphenols, increasing the nutritional value of wines, juice preparations and extracted oils, amongst other substances (Kapasakalidis et al., 2009). Enzymes such as cellulases, pectinases, xylanases and proteases are proteins that act in the degradation of compounds such as plant cell walls (plant cell wall degrading enzymes PCWDEs) (Beg et al., 2001), and can improve the extraction of polyphenols from green yerba mate. For instance, cellulases act on the degradation of cellulosic compounds by catalysing the breakdown of $\beta(1 \rightarrow 4)$ glycosidic bonds that bind the glucose molecules needed for cellulose formation. All the aforementioned enzymes are produced by various microorganisms, including actinomycetes, bacteria and fungi (Sharma et al., 2016). The enzyme-based extraction of bioactive compounds from plants is a potential alternative to conventional solvent-based extraction methods (Puri et al., 2012), for example, the RSM based optimized enzyme-assisted extraction of antioxidant phenolics from underutilized watermelon (Citrullus lanatus Thunb.) (Mushtaq et al., 2015). Enzyme-assisted extraction has the advantage of being a green alternative to 
conventional methods (Mushtaq et al., 2017). The aim of this research was to evaluate the best reaction time, temperature, enzyme concentration and $\mathrm{pH}$ to obtain polyphenols for industrial use from green yerba mate, using enzyme-assisted extraction as an alternative to conventional solvent extraction. For this purpose, a factorial experimental design and response surface methodology (RSM) were used, since these have been used as powerful statistical tools for studying the mutual interactions amongst variables over a range of values, while reducing the number of experimental trials (Moreira et al., 2014).

\section{Material and methods}

\subsection{Substrates}

Yerba mate (Ilex paraguariensis A. St. Hil.) leaves were collected in July 2016 from the region of São Mateus do Sul in the State of Paraná, Brazil. They were then processed in a traditional manner for enzymatic inactivation in a process called "sapeco". For this, the yerba is submitted to a temperature of $400{ }^{\circ} \mathrm{C}$ at the inlet, and $65^{\circ} \mathrm{C}$ at the outlet, with a mean time of 8 seconds. It is then dried in a dryer with a temperature ranging from 90 to $110{ }^{\circ} \mathrm{C}$ for about 3 hours, after which it is ground to a particle size of 2 to $3 \mathrm{~mm}$. The specimen was identified and deposited (voucher number 394262) at the Municipal Botanical Museum of Curitiba in the state of Paraná, Brazil. The commercial blend of enzymes Viscozyme ${ }^{\circledR}$ L, batch KTNO2241 (Novozymes, Denmark), was used for the enzymatic hydrolysis with $100 \mathrm{FGBU} / \mathrm{g}$ (FGBU = Fungal Beta-Glucanase units). This blend contains a range of carbohydrases consisting of arabanase, beta-glucanase, cellulase, hemicellulase and xylanase, and 1 unit of this enzyme (which hydrolyses beta-glucan to reducing sugars) corresponds to the production of $1 \mu \mathrm{mol}$ glucose per minute at $\mathrm{pH} 5.0$ and $30^{\circ} \mathrm{C}$ in 30 minutes. For the analysis of the polyphenols, the Folin Ciocalteau reagent (Sigma-Aldrich, USA) was used with gallic acid (Chromadex, USA) as the standard.

\subsection{Experimental design and statistical analysis}

The influence of temperature, enzyme (FGBU/g), reaction time and $\mathrm{pH}$ on the extraction of the polyphenols was evaluated using a $2^{4-1}$ CCRD (Central Composite Rotatable Design) with 8 axial points and 4 central points (Table 1). This design was used to determine properties such as randomness, rotatability and orthogonality for the best fit (Myers \& Montgomery, 2002). The quality of the polynomial model equation was determined statistically according to the coefficient of determination $\mathrm{R}^{2}$ and $p$-values below 0.05 were considered statistically significant. A pure error was used for the ANOVA analysis and all statistical analyses were carried out using the Statistica 13.2 software.

Table 1. Levels of the variables of the $2^{4-1}$ CCDR with 8 axial points and 4 central points used to evaluate the extraction of polyphenols from green yerba mate.

\begin{tabular}{cccccc}
\hline Variable & \multicolumn{5}{c}{ Level } \\
\cline { 2 - 6 } & $\mathbf{- 1 . 6 8 1 7 9}$ & $\mathbf{- 1}$ & $\mathbf{0}$ & $\mathbf{+ 1}$ & $\mathbf{+ 1 . 6 8 1 7 9}$ \\
\hline (1) Temperature $\left({ }^{\circ} \mathrm{C}\right)$ & 33.2 & 40.0 & 50.0 & 60.0 & 66.8 \\
(2) Enzyme $(\mathrm{FGBU} / 100 \mathrm{~g})$ & 0 & 68 & 168 & 268 & 336 \\
(3) Reaction time $(\mathrm{min})$ & 19 & 60 & 120 & 180 & 221 \\
$(4) \mathrm{pH}\left(25^{\circ} \mathrm{C}\right)$ & 2.82 & 3.50 & 4.50 & 5.50 & 6.18 \\
\hline
\end{tabular}

\subsection{Assays}

In the response surface optimization assays, 20 conical flasks $(250 \mathrm{~mL})$ were used to mix $4 \mathrm{~g}$ of yerba mate $+100 \mathrm{~mL}$ of water and enzyme according to Table 1 . The biotechnological experiment was carried out in a Dubnoff-type Metabolic Bath (Novatécnica, Brazil). The $\mathrm{pH}$ was evaluated by direct reading using a 
Q400A pH meter (Quimis, Brazil) according to the procedure described in the Brazilian Pharmacopoeia (European Directorate for the Quality of Medicines \& HealthCare, 2014).

\subsection{Assay for the total polyphenolic compounds}

The total polyphenolic compound concentrations in the dried leaves of the green yerba mate (Ilex paraguariensis A. St. Hil.) and in the enzymatic extracts were determined according to the European Pharmacopoeia (European Directorate for the Quality of Medicines \& HealthCare, 2014) using the Folin Ciocalteau (FC) reagent, determining the absorbance in a SP-1105 spectrophotometer (Spectrum, China) at $760 \mathrm{~nm}$, with gallic acid as the standard. This assay is based on the chemical reduction of the reagent containing sodium molybdate and sodium tungstate, which reacts with phenols and other substances such as ascorbic acid, aromatic amines, sugars and xanthines (Singleton et al., 1999).

\section{Results and discussion}

The experiments were carried out according to a central composite rotatable design (CCRD) considering the follow model: $2^{4-1} \mathrm{CCRD}+8$ axial points +4 central points. The coded values of the experimental factors and their levels for CCRD can be seen in Table 1. The incomplete design was carried out in a random manner in order to minimize the effect of non-controlled variables. A 4-factor design with 5-levels is suitable for exploring a quadratic response surface and constructing a second-order polynomial equation. An analysis of the results obtained from the CCRD allowed for made the following Equation (1) to be obtained:

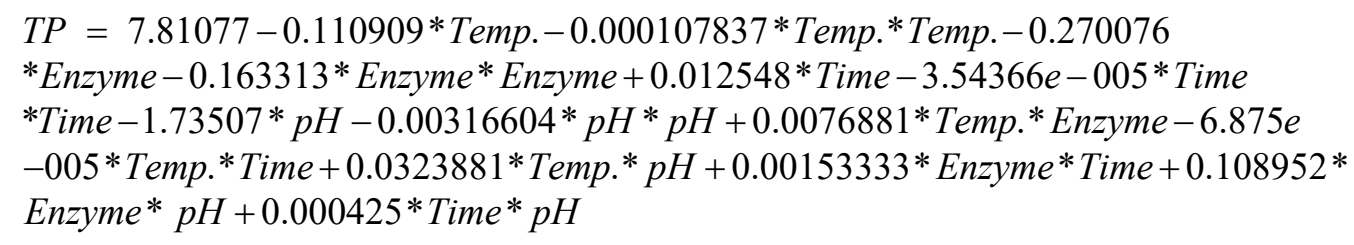

Table 2 shows the results obtained for the total polyphenol compounds extracted at the different temperatures $\left({ }^{\circ} \mathrm{C}\right)$, enzyme concentrations ( FGBU/100g), reaction times (min) and $\mathrm{pH}$ values. According to the Pareto chart (Figure 1) and ANOVA analysis (Table 3), the effects of all the variables were significant ( $p$ $\leq 0.05$ ) for the linear levels, while temperature and $\mathrm{pH}$ were not significant at the quadratic levels. The interactions between (1) temperature and (4) $\mathrm{pH}$; (2) enzyme concentration and (3) reaction time; (2) enzyme concentration and (4) $\mathrm{pH}$ were also significant $(p \leq 0.05)$. The regression model presented a determination coefficient $\left(\mathrm{R}^{2}\right)$ close to 0.85 and a fitted coefficient close to 0.45 . If the fitted R-squared decreases when a predictor improves the model less than expected by chance, the lower value obtained in this study can be justified due to the lack of difference in the quadratic values for the variables of temperature and $\mathrm{pH}$. The commercial enzyme used, Viscozyme ${ }^{\circledR} \mathrm{L}$, was previously used to optimize the extraction of polyphenol compounds from green tea (Camellia sinensis) and was the best choice amongst other commercial enzymes available, such as Celluclast ${ }^{\circledR}$, Cytolase $^{\circledR}$, Econase ${ }^{\circledR}$, Pectinex ${ }^{\circledR}$, Rapidase ${ }^{\circledR}$ and Ultraflo ${ }^{\circledR}$ (Hong et al., 2013). The same enzyme was also used for the pre-treatment of green tea residues and to improve the extraction of metabolites, where it was applied under mild conditions (temperature below $60^{\circ} \mathrm{C}$ ), since this preserves the integrity of other by-products such as pigments and polyphenols (Zhang et al., 2016). Many studies have demonstrated that the use of enzymes increases the amount of phenolic compounds extracted as well as the antioxidant activity (Cerda et al., 2013). The enzymatic extraction of polyphenolic compounds occurs via the hydrolytic degradation of polysaccharides from the plant cell wall, which retains the phenolic compounds in a network of polysaccharides and lignin bound by hydrogen or hydrophobic bonds. Another mechanism of enzymatic action is direct catalysis causing disruption of the ether and / or ester bonds between the phenols and polymers of the plant cell wall (Pinelo \& Meyer, 2008). 
Table 2. Total polyphenolic compounds (mg GAE/g) obtained from green yerba mate under different conditions of temperature $\left({ }^{\circ} \mathrm{C}\right)$, enzyme concentration (FGBU/100 g), reaction time (min) and $\mathrm{pH}$.

\begin{tabular}{cccccc}
\hline Run & Temp. $\left({ }^{\circ} \mathbf{C}\right)$ & $\begin{array}{c}\text { Enzyme } \\
\text { concentration } \\
\text { (FGBU/100 g) }\end{array}$ & Reaction time (min) & pH & $\begin{array}{c}\text { Total polyphenols } \\
\text { (mg GAE/ g) }\end{array}$ \\
\hline 1 & 60.00 & 268 & 180.00 & 3.50 & $3.180 \pm 0.005$ \\
2 & 60.00 & 268 & 60.00 & 3.50 & $2.745 \pm 0.022$ \\
3 & 60.00 & 68 & 180.00 & 5.50 & $3.241 \pm 0.066$ \\
4 & 40.00 & 268 & 60.00 & 5.50 & $2.281 \pm 0.018$ \\
5 & 60.00 & 68 & 60.00 & 5.50 & $3.072 \pm 0.018$ \\
6 & 40.00 & 68 & 180.00 & 3.50 & $2.890 \pm 0.005$ \\
7 & 40.00 & 268 & 180.00 & 5.50 & $2.983 \pm 0.080$ \\
8 & 40.00 & 68 & 60.00 & 3.50 & $2.658 \pm 0.033$ \\
9 & 33.20 & 168 & 120.00 & 4.50 & $2.435 \pm 0.055$ \\
10 & 66.80 & 168 & 120.00 & 4.50 & $3.400 \pm 0.066$ \\
11 & 50.00 & 0 & 120.00 & 4.50 & $2.084 \pm 0.070$ \\
12 & 50.00 & 336 & 120.00 & 4.50 & $2.890 \pm 0.036$ \\
13 & 50.00 & 168 & 19.00 & 4.50 & $1.803 \pm 0.022$ \\
14 & 50.00 & 168 & 221.00 & 4.50 & $3.371 \pm 0.044$ \\
15 & 50.00 & 168 & 120.00 & 2.82 & $2.788 \pm 0.005$ \\
16 & 50.00 & 168 & 120.00 & 6.18 & $3.090 \pm 0.013$ \\
$17(\mathrm{CP})$ & 50.00 & 168 & 120.00 & 4.50 & $3.168 \pm 0.078$ \\
$18(\mathrm{CP})$ & 50.00 & 168 & 120.00 & 4.50 & $3.125 \pm 0.013$ \\
\hline $19(\mathrm{CP})$ & 50.00 & 168 & 120.00 & 4.50 & $3.255 \pm 0.093$ \\
\hline $20(\mathrm{CP})$ & 50.00 & 168 & 120.00 & 4.50 & $3.130 \pm 0.063$ \\
\hline
\end{tabular}

$\mathrm{mg} \mathrm{GAE} / \mathrm{g}=\mathrm{mg}$ gallic acid equivalent/g; FGBU = Fungal Beta-Glucanase units; $\mathrm{CP}=$ central point.

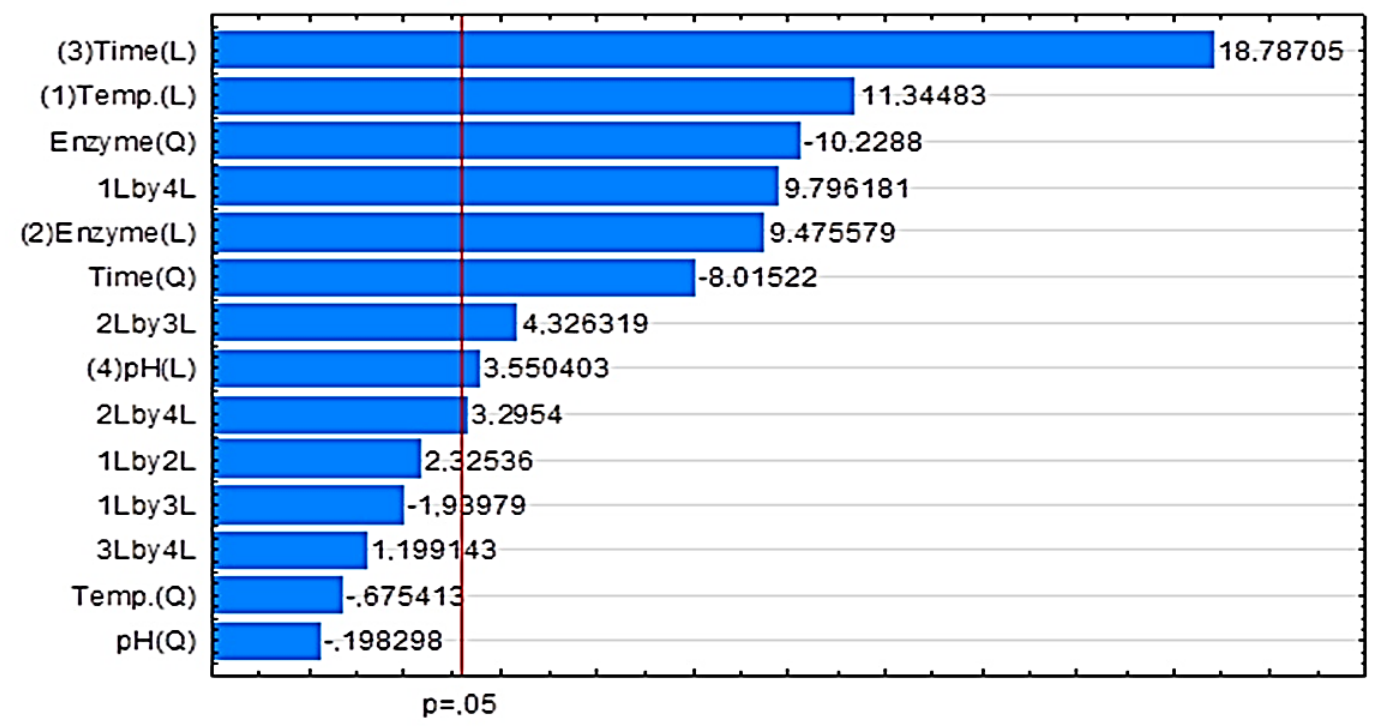

Figure 1. Pareto chart for the effects calculated from the responses of the $2^{4-1} \mathrm{CCRD}+8$ axial points +4 central points used to evaluate the extraction of polyphenolic compounds from green yerba mate considering (1) temperature $\left({ }^{\circ} \mathrm{C}\right),(2)$ enzyme concentration (FGBU/100 g), (3) reaction time (min) and (4) $\mathrm{pH}(p<0.05)$. 
Table 3. Analysis of variance (ANOVA) for the $2^{4-1}$ CCRD +8 axial points +4 central points used to evaluate the extraction of polyphenolic compounds from green yerba mate.

\begin{tabular}{|cccccc}
\hline Factor & SS & Df & MS & F & P \\
\hline (1) Temperature (L) & 0.465612 & 1 & 0.465612 & 128.7052 & 0.001469 \\
\hline (1) Temperature (Q) & 0.001650 & 1 & 0.001650 & 0.4562 & 0.547813 \\
(2) Enzyme (L) & 0.324818 & 1 & 0.324818 & 89.7866 & 0.002492 \\
(2) Enzyme (Q) & 0.378511 & 1 & 0.378511 & 104.6285 & 0.001992 \\
\hline (3) Reaction time (L) & 1.276867 & 1 & 1.276867 & 352.9532 & 0.000329 \\
(3) Reaction time (Q) & 0.232413 & 1 & 0.232413 & 64.2438 & 0.004054 \\
\hline (4) pH (L) & 0.045602 & 1 & 0.045602 & 12.6054 & 0.038080 \\
(4) pH (Q) & 0.000142 & 1 & 0.000142 & 0.0393 & 0.855489 \\
1L by 2L & 0.019562 & 1 & 0.019562 & 5.4073 & 0.102581 \\
\hline 1L by 3L & 0.013612 & 1 & 0.013612 & 3.7628 & 0.147742 \\
1L by 4L & 0.347170 & 1 & 0.347170 & 95.9652 & 0.002261 \\
2L by 3L & 0.067712 & 1 & 0.067712 & 18.7170 & 0.022767 \\
2L by 4L & 0.039287 & 1 & 0.039287 & 10.8597 & 0.045892 \\
3L by 4L & 0.005202 & 1 & 0.005202 & 1.4379 & 0.316550 \\
\hline Lack of fit & 0.508290 & 2 & 0.254145 & 70.2511 & 0.003023 \\
\hline
\end{tabular}

Variables and interactions in bold express significance $(p<0.05) . \mathrm{R}^{2}=0.85563$ Adjusted. $=0.45141 . \mathrm{SS}=$ sum-of-squares. $\mathrm{Df}=$ degrees of freedom. $\mathrm{MS}=$ mean square. $\mathrm{F}=\mathrm{f}$-ratio. $\mathrm{P}=\mathrm{p}$-value.

The presence of an enzyme increased the extraction of polyphenolic compounds from the dry green leaves of yerba mate (Figure 2a). Regarding enzyme concentration, it can be seen that the concentration of 336 (FGBU/100 g) (Table 2, run 12) increased the quantity of polyphenols by $38.67 \%$ in relation to extraction without the enzyme under the same experimental conditions (Table 2, run 11). An increase in the extraction of polyphenols was observed at the central points in which an intermediate enzyme concentration of $168 \mathrm{FGBU} / 100 \mathrm{~g}$ of dry green leaves of yerba mate was used, under the same experimental conditions of runs 11 and 12. For this scenario, the extraction of polyphenols increased by an average of $52.08 \%$ (four central points) (Table 2, runs 17-20) in relation to run 11 (without enzyme). This effect could be explained by the enzyme/substrate ratio, in which the excess of enzyme was used at quadratic levels and because the quantity of total polyphenols extracted decreased under this condition. Thus the best enzyme concentration for industrial viability was $168 \mathrm{FGBU} / 100 \mathrm{~g}$ of dry green leaves of yerba mate. The best conditions for the extraction of phenolics and flavonoids from roasted yerba mate leaves (Ilex paraguariensis A. St.-Hil., Aquifoliaceae) were determined using Response Surface Methodology (Bassani et al., 2014). The extraction of total polyphenolic compounds from yerba mate using ethanol was previously studied and the best parameters were: reaction time of $103 \mathrm{~min}$, extraction temperature of $71{ }^{\circ} \mathrm{C}$ and ethanol concentration of $61 \%$ (Bae et al., 2015). The enzyme-assisted extraction of secondary metabolites is considered to be a green and clean technology unlike the use of conventional solvents such as alcohols (methanol, ethanol), acetone, diethyl ether and ethyl acetate, which are used for the extraction of polyphenols despite several disadvantages such as possible hazardous effects on human health due to solvent residues in the final products, and the disposal of these solvents can also cause environmental problems (Mojzer et al., 2016). Enzymatic extraction is an alternative for the extraction of secondary metabolites, such as, for example, the enzymatic extraction of pilocarpine from Pilocarpus jaborandi, which increased the extraction 3.08 fold as compared to the control treatment (Cho et al., 2013). From green tea, enzymatic extraction showed a significant increase of $4 \%$ to $15 \%$ in the total polyphenolic compound content of the green tea extract when compared to the non- enzymatic treatment (Hong et al., 2013). Figure $2 \mathrm{~b}$ shows that the extraction of polyphenolic compounds increased at higher temperatures: at a temperature of $66.80{ }^{\circ} \mathrm{C}$ the amount of total polyphenolic compounds extracted increased by $7.27 \%$ in relation to the central point that used a temperature of $50^{\circ} \mathrm{C}$. Therefore an increase of $16.8^{\circ} \mathrm{C}$ is justified since it improves the extraction of the polyphenols. According to the literature, enzyme 
activity can be decreased by protein denaturation, which is an irreversible process involving the loss of the primary structure with the associated cleavage of covalent bonds at temperatures above $80{ }^{\circ} \mathrm{C}$ (Daniel et al., 1996). Nonetheless, the higher temperature did not show a significant effect when the $\mathrm{pH}$ was below 3.5 (Figure 2c). This result is in agreement with the current optimal conditions in which the ideal $\mathrm{pH}$ value is 3.3 to 5.5 (Hong et al., 2013). The reaction time had a significant effect on the extraction of polyphenols from green yerba mate (Figure 2d), although the amount of polyphenols extracted only increased by $6.35 \%$. Enzyme action is $\mathrm{pH}$ dependent (Bisswanger, 2014) and this was also observed in the present study where there was a significant interaction between (2) enzyme concentration and (4) $\mathrm{pH}$ (Figure 1 and Table 3). The change in $\mathrm{pH}$ alone was not significant and did not increase the extraction of polyphenols from yerba mate (Figure 2e), but the interaction between enzyme concentration and $\mathrm{pH}$ was observed to produce such an effect, although neither the $\mathrm{pH}$ alone for a short reaction time nor the interaction between the $\mathrm{pH}$ and reaction time produced a significant difference (Figure 2f). The optimization algorithm allowed for the elaboration of profiles for predicted response values and desirability functions (Figure 3); the red line indicates the best conditions and a desirability score of 1.0 : temperature of $50.0^{\circ} \mathrm{C}$, enzyme concentration of $168 \mathrm{FGB} / 100 \mathrm{~g}$, reaction time of 120 minutes and $\mathrm{pH}$ of 4.50 .

(a)

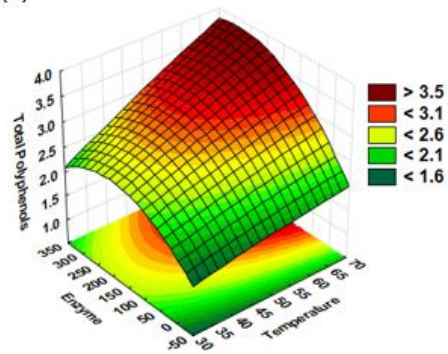

(c)

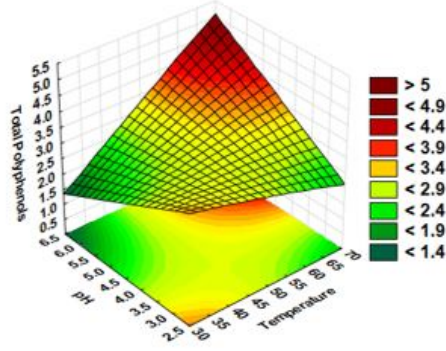

(e)

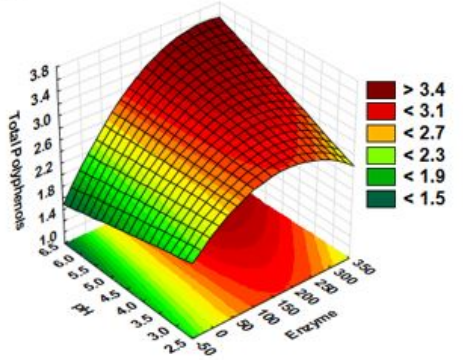

(b)

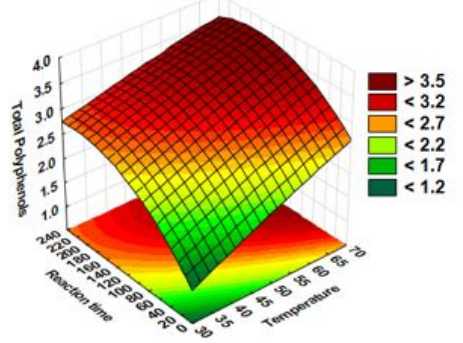

(d)

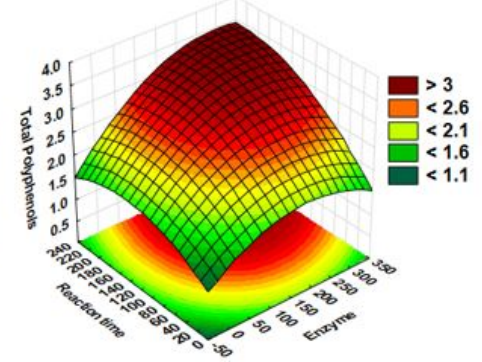

(f)

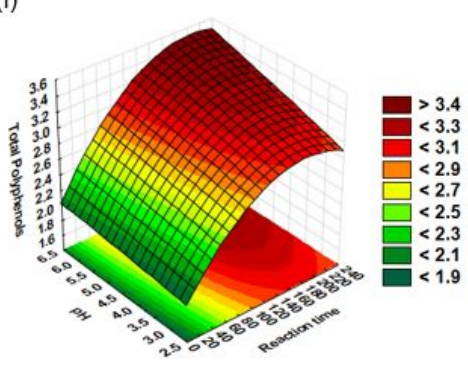

Figure 2. Response surfaces for the $2^{4-1} \mathrm{CCRD}+8$ axial points +4 central points to evaluate the extraction of polyphenolic compounds from green yerba mate. (a) temperature $\left({ }^{\circ} \mathrm{C}\right)$ : enzyme concentration (FGBU/100g). Fixed reaction time 120 minutes and fixed $\mathrm{pH} 4.5$; (b) temperature $\left({ }^{\circ} \mathrm{C}\right)$ : reaction time (minutes). Fixed enzyme concentration $168 \mathrm{FGBU} / 100 \mathrm{~g}$ and $\mathrm{pH} 4.5$; (c) temperature $\left({ }^{\circ} \mathrm{C}\right): \mathrm{pH}$. Fixed enzyme concentration $168 \mathrm{FGBU} / 100 \mathrm{~g}$ and reaction time 120 minutes; (d) reaction time (min): enzyme concentration (FGBU/100g). Fixed temperature $50^{\circ} \mathrm{C}$ and $\mathrm{pH} 4.5$; (e) $\mathrm{pH}$ : enzyme concentration (FGBU/100g). Fixed temperature $50^{\circ} \mathrm{C}$ and reaction time 120 minutes; (f) $\mathrm{pH}$ : reaction time (min). Fixed temperature $50^{\circ} \mathrm{C}$ and enzyme $168 \mathrm{FGBU} / 100 \mathrm{~g}$. 

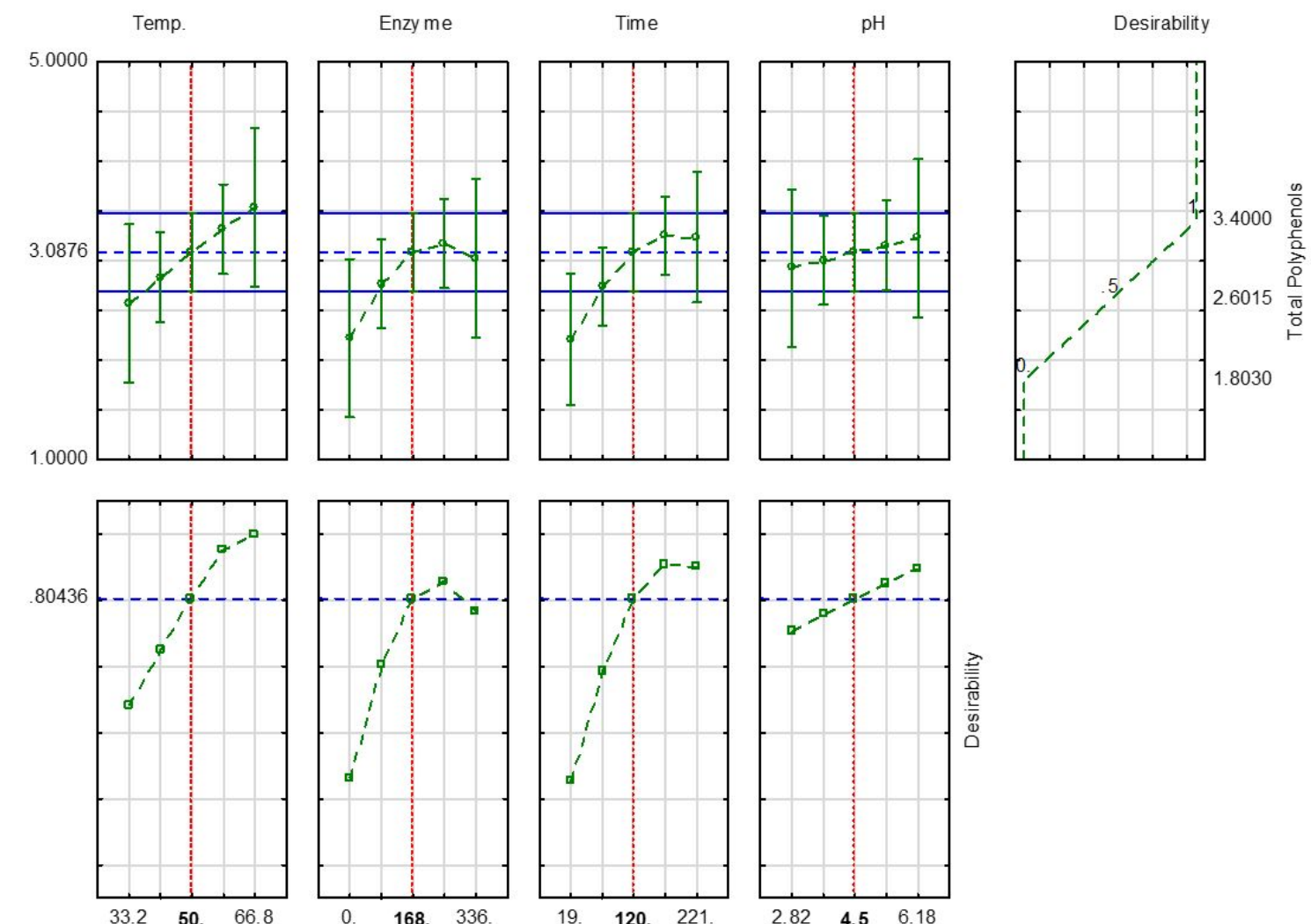

Figure 3. Profiles for the predicted values and desirability functions for the maximum extraction efficiency of total polyphenols from green yerba mate. Dotted red lines indicate the optimal values.

\section{Conclusion}

In this work a $2^{4-1} \mathrm{CCRD}+8$ axial points +4 central points was used to evaluate the extraction variables (temperature, enzyme concentration, reaction time and $\mathrm{pH}$ ) and possible interactions for the extraction of total polyphenolic compounds from the dried leaves of green yerba mate. By using response surfaces, contour curves and derivation techniques the optimum application conditions for the enzyme investigated were defined. It was concluded that the effects of all the variables studied (temperature, enzyme concentration, reaction time and $\mathrm{pH}$ ) were significant at the linear levels although temperature and $\mathrm{pH}$ were not significant at the quadratic levels, parameters that can be explained by the optimal enzymatic conditions. The interactions between temperature and $\mathrm{pH}$, enzyme concentration and reaction time and enzyme concentration and $\mathrm{pH}$ were significant. Based on the results obtained in this study and taking into account industrial viability, the authors suggest that the optimal conditions for the extraction of total polyphenols from green yerba mate are a temperature of $50.0^{\circ} \mathrm{C}$, enzyme concentration of $168 \mathrm{FGB} / 100 \mathrm{~g}$, reaction time of 120 minutes and $\mathrm{pH}$ of 4.5. The enzyme-assisted extraction of polyphenols from green yerba mate was considered a good alternative to conventional solvent extraction, since enzymes are renewable matter that further contribute to sustainable practices.

\section{Acknowledgements}

The authors wish to acknowledge Baldo S/A for donating the Ilex paraguariensis sample. 


\section{References}

Anesini, C., Turner, S., Cogoi, L., \& Filip, R. (2012). Study of the participation of caffeine and polyphenols on the overall antioxidant activity of mate (Ilex paraguariensis). Lebensmittel-Wissenschaft + Technologie, 45(2), 299-304. http://dx.doi.org/10.1016/j.Iwt.2011.06.015

Bae, I. K., Ham, H. M., Jeong, M. H., Kim, D. H., \& Kim, H. J. (2015). Simultaneous determination of 15 phenolic compounds and caffeine in teas and mate using RP-HPLC/UV detection: Method development and optimization of extraction process. Food Chemistry, 172, 469-475. PMid:25442580. http://dx.doi.org/10.1016/j.foodchem.2014.09.050

Bassani, D. C., Nunes, D. S., \& Granato, D. (2014). Optimization of phenolics and flavonoids extraction conditions and antioxidant activity of roasted yerba-mate leaves (Ilex paraguariensis A. St.-Hil., Aquifoliaceae) using response surface methodology. Anais da Academia Brasileira de Ciências, 86(2), 923-934. PMid:30514021. http://dx.doi.org/10.1590/00013765201420130019

Bastos, D. H. M., Oliveira, D. M., Matsumoto, R. L. T., Carvalho, P. O., \& Ribeiro, M. L. (2007). Yerba maté: Pharmacological Properties, Research and Biotechnology. Medicinal and Aromatic Plant Science and Biotechnology, 1(1), 37-46.

Beg, Q. K., Kapoor, M., Mahajan, L., \& Hoondal, G. S. (2001). Microbial xylanases and their industrial applications: A review. Applied Microbiology and Biotechnology, 56(3-4), 326-338. PMid:11548999. http://dx.doi.org/10.1007/s002530100704 Bisswanger, H. (2014). Enzyme assays. Perspectives on Science, 1(1-6), 41-55. http://dx.doi.org/10.1016/j.pisc.2014.02.005 Bracesco, N., Sanchez, A. G., Contreras, V., Menini, T., \& Gugliucci, A. (2011). Recent advances on Ilex paraguariensis research: Minireview. Journal of Ethnopharmacology, 136(3), 378-384. PMid:20599603. http://dx.doi.org/10.1016/j.jep.2010.06.032

Cerda, A., Martinez, M. A., Soto, C., Poirrier, P., Perez-Correa, J. R., Vergara-Salinas, J. R., \& Zúñiga, M. E. (2013). The enhancement of antioxidant compounds extracted from Thymus vulgaris using enzymes and the effect of extracting solvent. Food Chemistry, 139(1-4), 138-143. PMid:23561089. http://dx.doi.org/10.1016/j.foodchem.2012.12.044

Cho, J. H., Bhattarai, S., Oh, T. J., \& Jang, J. H. (2013). Enzymatic extraction of pilocarpine from Pilocarpus jaborandi. Korean Journal of Microbiology and Biotechnology, 41(2), 236-241. http://dx.doi.org/10.4014/kjmb.1303.03005

Craft, B. D., Kerrihard, A. L., Amarowicz, R., \& Pegg, R. B. (2012). Phenol-based antioxidants and the in vitro methods used for their assessment. Comprehensive Reviews in Food Science and Food Safety, 11(2), 148-173. http://dx.doi.org/10.1111/j.15414337.2011.00173.x

Daniel, R. M., Dines, M., \& Petach, H. H. (1996). The denaturation and degradation of stable enzymes at high temperatures. The Biochemical Journal, 317(Pt 1), 1-11. PMid:8694749. http://dx.doi.org/10.1042/bj3170001

European Directorate for the Quality of Medicines \& HealthCare - EDQM. (2014). European pharmacopoeia (8th ed.). Strasbourg: EDQM.

Geetha, T., Garg, A., Chopra, K., \& Pal Kaur, I. (2004). Delineation of antimutagenic activity of catechin, epicatechin and green tea extract. Mutation Research. Fundamental and Molecular Mechanisms of Mutagenesis, 556(1-2), 65-74. PMid:15491633. http://dx.doi.org/10.1016/j.mrfmmm.2004.07.003

Gugliucci, A., Bastos, D. H. M., Schulze, J., \& Souza, M. F. F. (2009). Caffeic and chlorogenic acids in Ilex paraguariensis extracts are the main inhibitors of AGE generation by methylglyoxal in model proteins. Fitoterapia, 80(6), 339-344. PMid:19409454. http://dx.doi.org/10.1016/j.fitote.2009.04.007

Heck, C. I., Schmalko, M., \& Mejia, E. G. (2008). Effect of growing and drying conditions on the phenolic composition of mate teas (Ilex paraguariensis). Journal of Agricultural and Food Chemistry, 56(18), 8394-8403. PMid:18759444. http://dx.doi.org/10.1021/jf801748s

Hong, Y. H., Jung, E. Y., Park, Y., Shin, K. S., Kim, T. Y., Yu, K. W., Chang, U. J., \& Suh, H. J. (2013). Enzymatic improvement in the polyphenol extractability and antioxidant activity of green tea extracts. Bioscience, Biotechnology, and Biochemistry, 77(1), 22-29. PMid:23291774. http://dx.doi.org/10.1271/bbb.120373

Kapasakalidis, P. G., Rastall, R. A., \& Gordon, M. H. (2009). Effect of a cellulase treatment on extraction of antioxidant phenols from black currant (Ribes nigrum L.) pomace. Journal of Agricultural and Food Chemistry, 57(10), 4342-4351. PMid:19354247. http://dx.doi.org/10.1021/jf8029176

Mejia, E. G., Song, Y. S., Heck, C. I., \& Ramires-Mares, M. V. (2010). Yerba mate tea (Ilex paraguariensis): Phenolics, antioxidant capacity and in vitro inhibition of colon cancer cell proliferation. Journal of Functional Foods, 2(1), 23-34. http://dx.doi.org/10.1016/j.jff.2009.12.003

Menini, T., Heck, C., Schulze, J., De Mejia, E., \& Gugliucci, A. (2007). Protective action of Ilex paraguariensis extract against free radical inactivation of paraoxonase-1 in high-density lipoprotein. Planta Medica, 73(11), 1141-1147. PMid:17823869. http://dx.doi.org/10.1055/s-2007-981585

Mojzer, E. B., Hrnčič, M. K., Škerget, M., Knez, Ž., \& Bren, U. (2016). Polyphenols: extraction methods, antioxidative action, bioavailability and anticarcinogenic effects. Molecules (Basel, Switzerland), 21(7), E901. PMid:27409600. http://dx.doi.org/10.3390/molecules21070901

Moreira, K. A., Herculano, P. N., Maciel, M. H. C., et al (2014). Optimization of phytase production by Aspergillus japonicus Saito URM 5633 using cassava bast as substrate in solid state fermentation. African Journal of Microbiological Research, 8(9), 929-938. http://dx.doi.org/10.5897/AJMR2013.6565

Mushtaq, M., Sultana, B., Akram, S., Anwar, F., Adnan, A., \& Rizvi, S. S. H. (2017). Enzyme-assisted supercritical fluid extraction: an alternative and green technology for non-extractable polyphenols. Analytical and Bioanalytical Chemistry, 409(14), 3645-3655. PMid:28331956. http://dx.doi.org/10.1007/s00216-017-0309-7 
Mushtaq, M., Sultana, B., Bhatti, H. N., \& Asghar, M. (2015). RSM based optimized enzyme-assisted extraction of antioxidant phenolics from underutilized watermelon (Citrullus lanatus Thunb.) rind. Journal of Food Science and Technology, 52(8), 50485056. PMid:26243925. http://dx.doi.org/10.1007/s13197-014-1562-9

Myers, R. H., \& Montgomery, D. C. (2002). Response surface methodology: process and product optimization using designed experiment. 2nd ed. New York: John Wiley and Sons.

Pinelo, M., \& Meyer, A. S. (2008). Enzyme-assisted extraction of antioxidants: release of phenols from vegetal matrixes. Electronic Journal of Environmental. Agricultural and Food Chemistry, 7(8), 3217-3220.

Puri, M., Sharma, D., \& Barrow, C. J. (2012). Enzyme-assisted extraction of bioactives from plants. Trends in Biotechnology, 30(1), 37-44. PMid:21816495. http://dx.doi.org/10.1016/j.tibtech.2011.06.014

Sharma, A., Tewari, R., Rana, S. S., Soni, R., \& Soni, S. K. (2016). Cellulases: Classification, Methods of Determination and Industrial Applications. Applied Biochemistry and Biotechnology, 179(8), 1346-1380. PMid:27068832. http://dx.doi.org/10.1007/s12010-016-2070-3

Singleton, V. L., Orthofer, R., \& Lamuela-Raventós, R. M. L. (1999). Analysis of total phenols and other oxidation substrates and antioxidants by means of folin-ciocalteu reagent. Methods in Enzymology, 299(1999), 152-178. https://doi.org/10.1016/S00766879(99)99017-1.

Zhang, C., Van Krimpen, M. M., Sanders, J. P. M., \& Bruins, M. E. (2016). Improving yield and composition of protein concentrates from green tea residue in an agri-food supply chain: effect of pre-treatment. Food and Bioproducts Processing, 100, 92-101. http://dx.doi.org/10.1016/j.fbp.2016.06.001 